\title{
HUBUNGAN KOMPENSASI FINANSIAL DAN STRES KERJA DENGAN KINERJA KARYAWAN PT. DOK DAN PERKAPALAN SURABAYA (PERSERO)
}

\author{
Mita Desy Yani, Endang Dwiyanti \\ Departemen Keselamatan dan Kesehatan Kerja \\ Fakultas Kesehatan Masyarakat Universitas Airlangga \\ Email: mitadshe@gmail.com
}

\begin{abstract}
The worker performance must be considered by company due to worker who have good performance can help the company to achieve its goal. Company should give responsibilities according to workers's ability and expertise for making good performance. The ups and down of worker performance happened because of the tough workload, uncomfortable work environment, and unfilled employee demands. This research analyzed the correlation between financial compensation and work stress on worker performance in PT. Dok and Perkapalan Surabaya (Persero). This research was descriptive which collected observationally with cross-sectional design. The population of study was construction worker in PT. Dok dan Perkapalan Surabaya (Persero), the sample was taken by total population which is consist of 40 workers. Independent variables were financial compensation and work stress. Dependent variable was worker performance. The primary data using questionnaires, observation, and interview while secondary data was profile company. The result from questionnaires were calculated using Spearman correlation. It showed that correlation level between financial compensation and worker performance was moderate with 0.332 correlation coefficient value. The level of correlation between work stress toward worker performance is moderate with 0.445 correlation coefficient value. It suggested to industry to improve the concern toward worker by creating safe and comfortable work environment. Giving reward to worker who has good achievement or who can create something useful for company.
\end{abstract}

Keywords: compensation financial, work stress, worker performance

\begin{abstract}
ABSTRAK
Kinerja karyawan harus diperhatikan oleh perusahaan, karena kinerja baik yang dihasilkan oleh karyawan dapat membantu perusahaan mencapai tujuan utama dari perusahaan. Perusahaan harus memberikan tanggung jawab sesuai kemampuan dan keahlian yang dimiliki karyawan agar kinerja yang dihasilkan baik. Kinerja karyawan sering kali mengalami pasang surut, hal tersebut dapat terjadi karena beban kerja yang berat, lingkungan yang tidak nyaman dan tuntutan karyawan terhadap tunjangan yang tidak dipenuhi perusahaan. Tujuan penelitian ini menganalisis hubungan kompensasi finansial dan stres kerja dengan kinerja karyawan di PT. Dok dan Perkapalan Surabaya (Persero). Penelitian ini adalah penelitian deskriptif, sedangkan ditinjau dari pengumpulan datanya bersifat observasional dengan cara pendekatan cross-sectional. Populasi dalam penelitian ini adalah karyawan PT. Dok dan Perkapalan Surabaya (Persero) bagian kontruksi yang berjumlah 40 orang, sedangkan sampel diambil dengan prinsip total populasi yaitu 40 karyawan. Variabel independen dalam penelitian ini adalah kompensasi finansial dan stres kerja. Variabel dependen adalah kinerja yang dihasilkan oleh karyawan. Data primer dan sekunder dalam penelitian ini diperoleh dari pabrik. Data primer menggunakan kuesioner, observasi dan wawancara. Data sekunder digunakan untuk gambaran umum perusahaan. Hasil yang telah didapat dari lembar kuesioner diolah dan dilakukan perhitungan menggunakan korelasi Spearman. Hasil penelitian menunjukkan bahwa tingkat hubungan antara kompensasi finansial dengan kinerja karyawan adalah sedang, dengan nilai korelasi koefisien sebesar 0,332. Tingkat hubungan antara stres kerja dengan kinerja karyawan adalah sedang, dengan nilai korelasi koefisien sebesar 0,445. Disarankan agar perusahaan meningkatkan perhatian terhadap karyawan dengan menciptakan lingkungan kerja yang aman dan nyaman, meningkatkan pengendalian lingkungan kerja. Memberikan reward kepada karyawan yang berprestasi atau karyawan yang berhasil menciptakan sesuatu yang bermanfaat untuk perusahaan.
\end{abstract}

Kata kunci: kompensasi finansial, stres kerja, kinerja karyawan

\section{PENDAHULUAN}

Sumber daya yang penting bagi suatu perusahaan adalah manusia. Peralatan dan perangkat canggih yang dimiliki oleh perusahaan tidak akan bisa bekerja sesuai dengan fungsinya jika tidak ada manusia sebagai tenaga kerja yang 
mengoperasikannya, oleh karena itu terdapat tuntutan pada karyawan untuk menunjukkan kinerjanya dengan baik.

Karyawan yang memiliki kinerja yang baik dapat membantu perusahaan untuk mencapai tujuan yang telah disepakati. Menurut Mangkunegara (2009), kinerja adalah hasil kerja yang dicapai oleh karyawan baik secara kualitas dan kuantitas karena tugas dan tanggung jawab yang diberikan oleh perusahaan telah dilaksanakan dengan baik. Dari pengertian tersebut menandakan bahwa perusahaan harus memberi tanggung jawab pada karyawannya sesuai dengan kemampuan dan keahlian yang dimiliki karyawannya.

Hasibuan (2003), menjelaskan bahwa kinerja merupakan suatu pencapaian hasil kerja seorang karyawan karena telah melaksanakan tugas yang telah diberikan berdasarkan atas pengalaman, kecakapan, dan kesungguhan. Kinerja dipengaruhi oleh 3 faktor, yaitu minat dan kemampuan dari seorang karyawan, kemampuan melaksanakan tugas, dan peran tingkat motivasi seseorang.

As'ad (2004), mengungkapkan bahwa banyak hal yang menyebabkan karyawan merasa tidak gembira, salah satunya adalah masalah kompensasi yang diterima. Kompensasi sangat penting bagi karyawan karena besar kecilnya kompensasi yang diberikan oleh perusahaan merupakan cerminan dari kinerja yang dihasilkan oleh karyawan tersebut.

Dessler dalam Subkhi (2012), menjelaskan kompensasi karyawan adalah semua imbalan atau pembayaran yang diterima oleh karyawan dari pekerjaan yang telah dilakukan karyawan tersebut. Pemberian sistem kompensasi yang efektif dapat membatu perusahaan untuk mempertahankan karyawan dengan kinerja baik karena manajemen sumber daya manusia sangat penting bagi perusahaan. Di samping itu kompensasi yang diterima karyawan mempengaruhi kinerja yang akan dihasilkan. Jadi secara umum dapat dikatakan bahwa kompensasi merupakan imbalan yang diberikan oleh perusahaan sebagai balas jasa kepada karyawan atas kinerja yang telah dihasilkan untuk perusahaan tersebut..

Penelitian yang telah dilakukan oleh Yulianto (2014), kompensasi berpengaruh signifikan terhadap kinerja karyawan Pabrik Gula Djatiroto. Sehingga dapat semakin besar kompensasi yang diberikan perusahaan kepada karyawannya, maka kinerja yang dihasilkan karyawan akan semakin meningkat.
Hasil penelitian yang dilakukan oleh Yensy (2010), mengungkapkan bahwa kompensasi berpengaruh signifikan dengan kinerja karyawan pada SMA Negeri 2 Argumakmur di Bengkulu Utara. Kompensasi dalam jangka panjang jika dapat dikelola dengan baik maka dapat dijadikan senjata yang efektif dan juga strategi memelihara dan mempertahankan semangat kerja dari karyawan.

Hasil penelitian yang dilakukan oleh Dhermawan dkk (2012), menyatakan bahwa kompensasi berpengaruh signifikan dengan kinerja karyawan di kantor dinas pekerjaan umum provinsi Bali. Hal ini dapat diartikan bahwa jika kompensasi yang diberikan perusahaan meningkat maka kinerja karyawan juga akan meningkat, sebaliknya jika kompensasi yang diterima oleh karyawan dari perusahaan tidak sesuai dengan yang seharusnya atau kurang, maka dampak yang terjadi di perusahaan adalah kinerja yang dihasilkan karyawan akan menurun.

Kinerja tidak hanya dipengaruhi oleh kompensasi, namun kinerja juga dapat dipengaruhi oleh stres kerja yang dialami oleh karyawan. Stres kerja adalah perasaan tidak nyaman atau tertekan yang dirasakan oleh karyawan karena pekerjaan, tempat bekerja dan situasi di tempat kerja yang kurang kondusif. Faktor yang mempengaruhi stres kerja antara lain yaitu faktor organisasi, faktor lingkungan, dan faktor individu. Yang termasuk dalam faktor dari organisasi yaitu tuntutan tugas, tuntutan antar pribadi, dan struktur organisasi (Robbins, 2008).

Stres kerja adalah suatu kondisi dari penghayatan subjektif individu yang dapat berupa interaksi antara individu dan lingkungan kerja yang dapat mengancam dan member tekanan secara psikologis, fisiologis dan sikap individu (Wijono, 2012). Efendi (2007), menjelaskan bahwa stres adalah dipengaruhinya pikiran, emosi dan fisik seseorang karena perasaan tertekan dalam menghadapi tuntutan pekerjaan yang cukup besar dan hambatan-hambatan lain dalam menyelesaikan pekerjaan.

Putri (2012), dalam penelitiannya mengungkapkan bahwa stres kerja dengan kinerja karyawan menghasilkan pengaruh yang signifikan di PT. United Motors Centre Pusat Surabaya. Hasil tersebut dapat disebabkan bila karyawan tidak merasa stres, maka kinerja mereka menurun karena karyawan merasa tidak ada tantangan dalam 
bekerja. Begitu juga sebaliknya, hal ini terjadi karena karyawan merasa dengan adanya stres kerja membuat mereka mampu mengerahkan keterampilan yang dimiliki untuk dapat menyelesaikan tugas dengan baik. PT. Dok dan Perkapalan Surabaya (Persero) merupakan perusahaan BUMN yang bergerak di bidang pembuatan kapal baru dan perbaikan kapal. PT. Dok dan Perkapalan Surabaya merupakan perusahaan BUMN produksi kapal terbesar kedua setelah PT. PAL Surabaya (Persero). Dalam struktur kerja PT. Dok dan Perkapalan Surabaya terdapat beberapa bagian salah satunya yaitu bagian produksi.

Bagian produksi dibagi menjadi beberapa bagian, salah satunya adalah bagian konstruksi. Sistem kerja pada bagian konstruksi menggunakan sistem target. Sistem target yang dimaksud yaitu misalnya saja ada kapal yang ingin melakukan perbaikan kapalnya di PT. Dok dan Perkapalan Surabaya. Sebelum kapal naik ke dok terdapat kontrak kerja yang telah disepakati oleh pihak kapal dan PT. Dok dan Perkapalan Surabaya bahwa perbaikan kapal akan selesai dalam waktu sekian minggu atau bulan. Untuk itu karyawan pada bagian produksi dituntut untuk menyelesaikan pekerjaan sesuai waktu yang telah disepakati bagaimanapun caranya. Bahkan beberapa karyawan menyampaikan bahwa mereka harus sering lembur untuk menyelesaikan tugas mereka. Sistem kerja yang seperti ini dapat menjadi pemicu timbulnya stres pada karyawan.

Karyawan juga mengeluhkan tentang pemberian kompensasi. Meskipun, kompensasi yang diberikan sudah sesuai dengan UMR yang berlaku dan mereka mendapatkan berbagai tunjangan seperti uang makan dan transport namun akhir-akhir ini karyawan PT. Dok dan Perkapalan Surabaya mengeluhkan bahwa pemberian uang tunjangan sedikit tersendat karena finansial perusahaan yang sedang bermasalah. Bahkan pemberian gaji karyawan pernah mundur dari tanggal yang seharusnya karena masalah tersebut. Hal ini mengakibatkan karyawan menjadi malas bekerja.

Penelitian ini bertujuan untuk menganalisis hubungan antara kompensasi finansial dan stres kerja dengan kinerja karyawan di PT. Dok dan Perkapalan Surabaya (Persero).

\section{METODE}

Penelitian ini adalah penelitian deskriptif, sedangkan ditinjau dari pengumpulan datanya bersifat observasional. Variabel dalam penelitian ini diukur satu kali dan satu waktu saja sehingga dari segi pelaksanaan waktu penelitian termasuk penelitian cross-sectional karena pengukuran variabel pada saat tertentu dan hanya satu kali pada setiap sujek yang diteliti (Notoatmojo, 2005).

Penelitian ini berlokasi di bagian konstruksi PT. Dok dan Perkapalan Surabaya (Persero). Penelitian ini berlangsung selama 3 bulan yaitu bulan September sampai dengan Desember 2015yang meliputi kegiatan perizinan, pengumpulan data dan rekapan dari hasil penelitian. Populasi pada penelitian ini yaitu karyawan bagian konstruksi PT. Dok dan Perkapalan Surabaya (Persero) yang berjumlah 40 orang. Sampel dari penelitian ini menggunakan total populasi yaitu 40 orang karyawan bagian konstruksi.

Terdapat dua variabel yang diukur dalam penelitian ini yaitu variabel independen dan variabel dependen. Variabel independen yang diukur adalah kompensasi finansial yang diterima oleh karyawan bagian kontruksi dan stres kerja yang dialami oleh karyawan. Sedangkan variabel dependen adalah kinerja yang dihasilkan oleh karyawan bagian konstruksi. Hasil yang telah didapat dari lembar kuesioner diolah dan dilakukan perhitungan menggunakan korelasi Spearman.

\section{HASIL}

\section{Proses Produksi di Bagian Konstruksi PT. Dok dan Perkapalan Surabaya Persero}

Terdapat beberapa tahapan pekerjaan yang dilakukan di bagian kontruksi yaitu:

\section{Fabrikasi}

Proses fabrikasi merupakan proses lanjutan dari proses desain. Dalam proses ini plat yang masih dalam bentuk lembaran akan diubah kedam bentuk profil maupun plat kulit setelah melewati beberapa tahapan yaitu pembersihan plat, pelurusan plat, proses marking .

\section{Proses cutting}

Pemotongan yang dilakukan pada material yang telah di marking. Marking akan dilakukan jika pihak QA (Quality Assurance) telah menyetujui sehingga material tersebut dapat dipotong. Banyak faktor yang dapat mempengaruhi hasil pemotongan, misalnya operator, kualitas hasil potongan material dipengaruhi keahlian dari operator. 


\section{Sub assembly}

Penggabungan material dari bengkel fabrikasi menjadi blok-blok kecil (part assembly). Material berupa plat lurus maupun plat bengkok, dan plat yang dilengkungkan.

\section{Distribusi Variabel}

Tabel 1. Distribusi Kompensasi Karyawan di Bagian Konstruksi PT. Dok dan Perkapalan Surabaya Desember, 2015

\begin{tabular}{lrr}
\hline \multicolumn{1}{c}{ Kompensasi Finansial } & N & \% \\
\hline Sangat tinggi & 8 & 20 \\
Tinggi & 16 & 40 \\
Sedang & 12 & 30 \\
Rendah & 4 & 10 \\
\hline Jumlah & 40 & 100 \\
\hline
\end{tabular}

Sumber: Data Primer

Berdasarkan data pada Tabel 1 dapat diketahui bahwa karyawan di bagian konstruksi sebagian besar mendapatkan kompensasi tinggi yaitu sebanyak $40 \%$. Sedangkan sebagian kecil karyawan mendapat kompensasi rendah yaitu $10 \%$.

Stres kerja pada penelitian ini dikelompokkan menjadi 4 kategori yaitu rendah atau tidak stres, sedang, tinggi, dan sangat tinggi.

Data yang diperoleh dari responden menunjukkan bahwa sebagian besar karyawan mengalami stres kerja sedang yaitu 31 orang (77.5\%), sedangkan sebagian kecil karyawan tidak mengalami stres kerja/stres kerja rendah sebanyak $22,5 \%$. Karyawan yang mengalami stres kerja tinggi dan sangat tinggi tidak ada, seperti yang tertera pada tabel 2 berikut ini.
Tabel 2. Distribusi Distribusi Stres Kerja Karyawan di Bagian Kontruksi PT. Dok dan Perkapalan Surabaya Desember, 2015

\begin{tabular}{lrc}
\hline \multicolumn{1}{c}{ Stres Kerja } & N & \% \\
\hline Rendah/tidak stres & 9 & 22,5 \\
Sedang & 31 & 77,5 \\
Tinggi & 0 & 0 \\
Sangat tinggi & 0 & 0 \\
\hline Jumlah & 40 & 100 \\
\hline
\end{tabular}

Sumber: Data Primer

Kinerja karyawan pada penelitian ini dibagi dalam 3 kategori, yaitu kinerja baik, kinerja cukup, dan kinerja kurang.

Tabel 3 menunjukkan bahwa sebagian besar karyawan di bagian kontruksi memiliki kinerja yang baik yaitu sebanyak 26 orang (65\%), sedangkan karyawan yang mengalami stres kerja rendah/tidak stres sebanyak 9 orang $(22,5 \%)$.

Tabel 3. Distribusi Distribusi Kinerja Karyawan di Bagian Kontruksi PT. Dok dan Perkapalan Surabaya Desember, 2015

\begin{tabular}{lrr}
\hline \multicolumn{1}{c}{ Kinerja } & N & \% \\
\hline Baik & 26 & 65 \\
Cukup & 14 & 35 \\
Kurang & 0 & 0 \\
\hline Jumlah & 40 & 100 \\
\hline
\end{tabular}

Sumber: Data Primer

\section{Hubungan Antar Variabel}

Hasil tabulasi silang antara variabel kompensasi dan kinerja karyawan seperti pada tabel 4 menunjukkan bahwa sebagian besar karyawan

Tabel 4. Hubungan Antara Kompensasi dengan Kinerja Karyawan PT. Dok dan Perkapalan Surabaya Desember, 2015

\begin{tabular}{|c|c|c|c|c|c|c|c|c|}
\hline \multirow{3}{*}{ Kompensasi Finansial } & \multicolumn{6}{|c|}{ Kinerja } & \multicolumn{2}{|c|}{ Total } \\
\hline & \multicolumn{2}{|c|}{ Kurang } & \multicolumn{2}{|c|}{ Cukup } & \multicolumn{2}{|c|}{ Baik } & \multirow{2}{*}{$\mathbf{n}$} & \multirow{2}{*}{$\%$} \\
\hline & $\mathbf{n}$ & $\%$ & $\mathbf{n}$ & $\%$ & $\mathbf{n}$ & $\%$ & & \\
\hline Sangat tinggi & 0 & 0,0 & 0 & 0,0 & 8 & 100,0 & 8 & 100,0 \\
\hline Tinggi & 0 & 0,0 & 1 & 6,2 & 15 & 93,8 & 16 & 100,0 \\
\hline Sedang & 0 & 0,0 & 10 & 83,3 & 2 & 16,7 & 12 & 100,0 \\
\hline Rendah & 0 & 0,0 & 3 & 75,0 & 1 & 25,0 & 4 & 100,0 \\
\hline Total & 0 & 0,0 & 14 & 35,0 & 26 & 65,0 & 40 & 100,0 \\
\hline
\end{tabular}

Sumber: Data Primer 
Tabel 5. Hubungan Antara Stres Kerja dengan Kinerja Karyawan PT Dok dan Perkapalan Surabaya Desember, 2015

\begin{tabular}{|c|c|c|c|c|c|c|c|c|}
\hline \multirow{3}{*}{ Stres Kerja } & \multicolumn{6}{|c|}{ Kinerja } & \multicolumn{2}{|c|}{ Total } \\
\hline & \multicolumn{2}{|c|}{ Kurang } & \multicolumn{2}{|c|}{ Cukup } & \multicolumn{2}{|c|}{ Baik } & \multirow{2}{*}{$\mathbf{n}$} & \multirow{2}{*}{$\%$} \\
\hline & $\mathbf{n}$ & $\%$ & $\mathbf{n}$ & $\%$ & $\mathbf{n}$ & $\%$ & & \\
\hline Rendah/tidak stres & 0 & 0,0 & 5 & 55,6 & 4 & 44,4 & 9 & 100,0 \\
\hline Sedang & 0 & 0,0 & 9 & 29,0 & 22 & 71,0 & 31 & 100,0 \\
\hline Tinggi & 0 & 0,0 & 0 & 0,0 & 0 & 0,0 & 0 & 0,0 \\
\hline Sangat tinggi & 0 & 0,0 & 0 & 0,0 & 0 & 0,0 & 0 & 0,0 \\
\hline Total & 0 & 0,0 & 14 & 35,0 & 26 & 65,0 & 40 & 100,0 \\
\hline
\end{tabular}

Sumber: Data Primer

yang mendapatkan kompensasi tinggi, kinerja yang dihasilkan baik yaitu sebanyak 15 orang $(93,8 \%)$. Hal ini menunjukkan jika pemberian kompensasi sesuai dengan apa yang diharapkan karyawan maka kinerja yang dihasilkan akan cenderung semakin baik. Untuk itu pemberian kompensasi kepada karyawan harus sangat diperhatikan karena kompensasi bagi karyawan itu sangat penting.

Hasil perhitungan menggunakan korelasi Spearman tingkat hubungan antara variabel kompensasi finansial dan kinerja adalah sedang dengan nilai kontingensi koefisien sebesar 0,332.

Hasil tabulasi silang antara variabel stres kerja dan kinerja seperti yang dapat dilihat pada tabel 5 diketahui bahwa stres kerja sedang sebagian besar dialami oleh karyawan yang memiliki kinerja baik yaitu sebanyak 22 orang $(71,0 \%)$, hal ini dapat diartikan bahwa jika karyawan mengalami stres kerja sedang maka kinerja yang dihasilkan baik.

Hasil perhitungan menggunakan korelasi Spearman tingkat hubungan antara stres kerja dan kinerja karyawan adalah sedang dengan nilai kontingensi koefisien sebesar 0,445.

\section{PEMBAHASAN}

\section{Kompensasi Finansial}

Dessler dalam Subkhi (2012) menyatakan bahwa kompensasi karyawan adalah imbalan pembayaran dari perusahaan yang diberikan kepada karyawan dari pekerjaan yang telah dilakukan karyawan tersebut. Pemberian sistem kompensasi yang efektif dapat membatu perusahaan untuk mempertahankan karyawan dengan kinerja baik karena manajemen sumber daya manusia sangat penting bagi perusahaan. Kompensasi yang diterima karyawan mempengaruhi kinerja yang akan dihasilkan oleh karyawan tersebut.
Kompensasi bisa meningkatkan ataupun justru menurunkan kinerja karyawan. Pemberian kompensasi kepada karyawan perlu mendapat perhatian lebih dari perusahaan. Kompensasi harus memiliki dasar yang kuat, benar dan adil. Apabila karyawan merasa kompensasi yang diberikan tidak adil maka tentu saja karyawan akan merasa dirugikan dan kecewa, yang mengakibatkan karyawan memilih untuk keluar perusahaan tersebut, oleh sebab itu untuk mempertahankan karyawan yang berkompeten agar tetap bekerja di perusahaan maka pemberian kompensasi harus dipikirkan sedemikian rupa sehingga karyawan akan merasa dihargai (Muljani, 2002).

Sedarmayati (2009), menjelaskan bahwa tujuan pemberian kompensasi yaitu menghargai prestasi kerja; memberikan kompensasi yang layak merupakan penghargaan yang diterima karyawan karena prestasi kerja yang diberikan kepada perusahaan. Dengan demikian akan membuat karyawan terdorong untuk menghasilkan kinerja yang baik sesuai dengan harapan perusahaan. Keadilan terjamin; kualitas karyawan dalam perusahaan akan terjamin karena adanya sistem kompensasi yang baik. Imbalan yang diperoleh karyawan harus sesuai dengan prestasi yang dihasilkan karyawan, jabatan, tanggung jawab, dan tugas dari karyawan tersebut. Mempertahankan pegawai; karyawan akan tetap bertahan dalam perusahaan jika ditunjang dengan sistem kompensasi yang baik, hal itu dapat diartikan bahwa karyawan tidak akan keluar dari perusahaan untuk mencari pekerjaan yang lebih baik menurut mereka. Memperoleh pegawai yang bermutu; calon pegawai baru akan mudah didapat dengan adanya sistem kompensasi yang baik. Pemilihan calon pegawai yang berkompeten akan lebih luas peluangnya karena banyaknya calon pegawai yang melamar. Pengendalian biaya; pelaksanaan 
rekrutmen pegawai tidak akan sering dilakukan jika sistem kompensasi baik. Pengeluaran perusahaan untuk rekrutmen pegawai pun dapat diminimalisir. Memenuhi peraturan; pemberian kompensasi dalam bentuk gaji maupun upah harus sesuai dengan peraturan yang telah ditetapkan oleh pemerintah sehingga kebutuhan karyawan dapat terpenuhi dengan baik.

Hasil penelitian yang telah dilakukan maka didapatkan hasil bahwa sebagian besar responden mendapatkan kompensasi tinggi (40\%). Karyawan yang mendapatkan kompensasi tinggi ini pada umumnya adalah karyawan yang masa kerjanya terbilang lama, karena sistem pemberian kompensasi di PT. Dok dan Perkapalan Surabaya berdasarkan lama kerja karyawan. Kompensasi yang diterima karyawan tidak hanya gaji pokok saja, namun karyawan juga mendapatkan tunjangan makan, uang transport dan uang lembur apabila mereka bekerja di luar jam kerja yang sudah ditetapkan.

\section{Stres Kerja}

Hasil penelitian menunjukkan bahwa sebagian besar responden mengalami stres kerja yaitu sebanyak 31 orang $(77,5 \%)$ sedangkan 7 orang lainnya $(22,5 \%)$ tidak mengalami stres. Karyawan di bagian konstruksi sering mengeluhkan bahwa beban kerja yang dibebankan kepada mereka dirasa cukup berat karena sistem kerja pada bagian ini menggunakan sistem target. Karyawan harus sering lembur untuk memenuhi target yang telah disepakati antara pihak kapal dan perusahaan. Beban kerja sedikit dan beban kerja berlebih merupakan salah satu pemicu terjadinya stres. Beban kerja merupakan suatu tuntutan yang berasal dari luar tubuh pekerja dalam melaksanakan pekerjaan. Beban kerja bisa berupa beban kerja fisik dan beban kerja mental (Tarwaka, 2011).

Tarwaka (2011), menjelaskan bahwa stres kerja adalah perasaan tertekan yang berlebih atau merasa beban kerja yang diterima berlebih sehingga menimbulkan reaksi negatif dari dalam tubuh. Akan tetapi, pengendalian stres yang tepat dapat merubah stres tersebut menjadi stres kerja yang positif, gangguan kesehatan akan muncul jika stres kerja yang dialami tidak dikendalikan dengan baik.

Winarsunu (2008), mengungkapkan bahwa konsumsi kalori saja tidak cukup untuk memperkirakan beban kerja fisik, namun juga dapat dilihat dari otot yang terlibat, beban non dinamis, serta perhitungan denyut nadi. Dari pernyataan tersebut dapat menunjukkan bahwa perhitungan denyut nadi dapat digunakan untuk mengetahui beban kerja.

Kondisi lingkungan kerja yang berdebu, panas dan kurang penerangan di dalam kapal dan tidak nyaman juga dapat mengganggu proses kerja karyawan.

Lingkungan kerja harus diatur sedemikian rupa agar dapat memberikan rasa nyaman bagi orang yang berada pada lingkungan tersebut, karena lingkungan kerja yang nyaman dapat menjadi dorongan tersendiri untuk karyawan dalam melakukan pekerjaannya dan membuat karyawan bersemangat serta tidak merasa jenuh.

Wijono (2012), mengungkapkan bahwa kondisi lingkungan kerja yang dirasa kurang kondusif oleh karyawan maka dapat menimbulkan rasa tidak puas yang pada akhirnya dapat membuat karyawan murung, mudah marah dan cepat lelah.

Sedarmayanti (2009), menjelaskan bahwa lingkungan kerja yang nyaman memiliki penerangan yang cukup terang dan tidak menyilaukan. Pekerjaan yang dilakukan karyawan dapat terhambat dan sering terjadi kesalahan jika cahaya atau penerangan dalam tempat kerja kurang jelas. Sirkulasi udara di tempat kerja juga harus diperhatikan, jika udara di tempat kerja kotor dan berdebu tentunya akan mengganggu kenyamanan karyawan. Tanaman di sekitar tempat kerja merupakan sumber daru udara segar karena tanaman dapat menghasilkan oksigen yang sangat dibutuhkan oleh setiap manusia.

Stres kerja mungkin positif atau negative bagi tenaga kerja. Reaksi tubuh terhadap stres dapat membantu tenaga kerja untuk berkonsentrasi dalam melakukan sesuatu. Beberapa tenaga kerja dapat bekerja lebih baik di bawah tekanan. Secara umum, ada taraf optimum stres pada karyawan untuk mengerjakan tugas-tugas tertentu. Taraf optimum dalam stres adalah degree of arousal perfoemance, yang berarti taraf tinggi rendahnya stres akan mempengaruhi efesiensi performasi, pada titik optimum stres dapat meningkatkan efisiensi performasi dan pada taraf stres yang melebihi titik optimum akan menurunkan efiensi performasi (Winarsunu, 2008).

\section{Kinerja}

Hasil penelitian yang dilakukan di PT. Dok dan Perkapalan Surabaya bagian kontruksi 
menunjukkan bahwa sebagian besar karyawan memiliki kinerja yang baik yaitu sebanyak 26 orang (65\%), sedangkan sisanya memiliki kinerja yang cukup (35\%). Karyawan di PT. Dok dan Perkapalan memiliki kinerja yang baik karena karyawan merasa ditempatkan atau memiliki tugas sesuai dengan keahlian yang dimiliki dan memiliki cukup pengalaman bekerja pada bidang tersebut dalam waktu cukup lama. Hal ini sesuai dengan yang diungkapkan Hasibuan (2003), kinerja pencapaian hasil kerja oleh seorang karyawan karena telah melaksanakan tugas dari perusahaan dengan baik berdasarkan pengalaman dan keterampilan yang dimiliki. Kinerja dipengaruhi tiga faktor penting, yaitu kemampuan dan minat seorang pekerja, kemampuan melaksanakan tugas, dan peran tingkat motivasi seseorang.

Handoko (2000), mengungkapkan penilaian kinerja terdiri dari 3 kriteria yaitu penilaian berdasarkan hasil adalah penilaian yang dapat diukur secara spesifik dan berdasarkan target yang telah ditetapkan, penilaian berdasarkan perilaku adalah penilaian yang berkaitan dengan perilaku dalam bekerja, penilaian berdasarkan judgement yaitu penilaian yang berdasarkan kualitas dan kuantitas pekerjaan, keterampilan, semangat dalam bekerja, kerja sama, kepribadian dan dapat menyelesaikan tugas dan kepercayaan yang diberikan dengan baik.

Mathis dan Jackson (2002), mengungkapkan bahwa penilaian kerja karyawan dapat digunakan untuk 2 hal yaitu penggunaan administratif adalah penilaian kinerja adalah harapan dari karyawan untuk mendapatkan penghargaan karena telah menghasilkan kinerja yang baik untuk perusahaan, penggunaan untuk pengembangan adalah penilaian kinerja merupakan kunci untuk mengembangkan kompetensi yang dimiliki karyawan dan dapat menjadi sumber informasi utama untuk perusahaan.

\section{Hubungan antara Kompensasi Finansial dengan Kinerja Karyawan}

Hasil yang diperoleh antara variabel kompensasi dan kinerja karyawan menunjukkan bahwa sebagian besar karyawan yang mendapatkan kompensasi finansial tinggi kinerja yang dihasilkan baik yaitu sebanyak 15 orang $(37.5 \%)$. Berdasarkan hasil perhitungan menggunakan korelasi Spearman diperoleh hasil bahwa tingkat hubungan kedua variabel termasuk dalam tingkat hubungan sedang dengan nilai Correlation Coefficient sebesar 0,332.
Mathin dan Jackson dalam Simamora (2004), mengungkapkan bahwa kompensasi finansial bagi karyawan adalah penting, karena kebutuhan langsung seperti kebutuhan fisiologis dari karyawan dapat terpenuhi dengan kompensasi yang mereka dapatkan. Karyawan juga berharap mereka menerima kompensasi sesuai dengan pengorbanan yang telah diberikan kepada perusahaan.

Handoko (2001), mengemukakan bahwa kompensasi merupakan persepsi karyawan terhadap berbagai bentuk imbalan yang diperoleh dari hasil melakukan pekerjaan yang digambarkan dalam dua jenis kompensasi diantaranya kompensasi langsung meliputi gaji dan upah. Sedangkan kompensasi tidak langsung seperti penyelenggaraan program pelayanan karyawan seperti pelayanan kesehatan karyawan.

Berdasarkan hasil observasi yang telah dilakukan di lapangan kesesuaian pemberian kompensasi baik gaji maupun tunjangan untuk karyawan telah disesuaikan dengan tanggung jawab pekerjaan, meskipun pekerjaan yang dilakukan terlihat berat akan tetapi dengan pemberian gaji dan bonus yang sesuai dengan kebutuhan karyawan akan merangsang kinerja dari karyawan sehingga tujuan perusahaan akan tercapai.

Sulistiyowati (2005), menjelaskan bahwa tujuan perusahaan memberikan kompensasi adalah agar karyawan termotivasi sehingga kinerja dari karyawan dapat ditingkatkan dan karyawan dengan kompetensi baik tetap bekerja di perusahaan tersebut. Bagi seorang karyawan kompensasi selalu menjadi perhatian utama karena kompensasi adalah sumber pendapatan dari keterampilan yang dimiliki. Karyawan menganggap bahwa kompensasi adalah sebagai pertukaran atas jasa yang telah diberikan atau penghargaan atas pekerjaan yang telah mereka lakukan yang nantinya menjadi cerminan keahlian dan kemampuan individu. Hal ini sesuai dengan pendapat yang dikemukakan Panggabean dan Mutiara (2004), yang menyatakan bahwa pemberian kompensasi kepada karyawan dapat meningkatkan kinerja dari karyawan. Kompensasi berupa uang lebih dapat meningkatkan kinerja dari karyawan dari pada dengan menggunakan teknik lain.

\section{Hubungan antara Stres Kerja dengan Kinerja Karyawan}

Hasil penelitian menunjukkan bahwa sebagian besar karyawan yang mengalami stres kerja sedang menghasilkan kinerja yang baik yaitu sebanyak 
22 orang (55\%). Sedangkan berdasarkan hasil perhitungan menggunakan korelasi Spearman diperoleh hasil bahwa tingkat hubungan kedua variabel termasuk dalam tingkat hubungan sedang dengan nilai Correlation Coefficient sebesar 0,445. Hal tersebut dapat disebabkan karyawan merasa tidak ada tantangan kerja jika tidak adanya stres kerja sehingga kinerja yang dihasilkan oleh karyawan menurun. Sebaliknya juga akan demikian, karena dengan adanya stres maka karyawan mendapatkan dorongan untuk mengerahkan kemampuan dan keterampilan yang dimiliki untuk menyelesaikan pekerjaan yang telah diberikan oleh perusahaan sebaik mungkin. Stres kerja akan mencapai titik stabil sesuai dengan kemampuan dan keterampilan seorang karyawan jika mendapatkan dorongan positif dari diri karyawan itu sendiri untuk menyelesaikan tantangan pekerjaan dari perusahaan. Hasil penelitian Hidayati dkk (2008), menunjukkan bahwa terdapat hubungan negatif yang signifikan antara stres kerja dengan kinerja karyawan. Hal ini menunjukkan bahwa kinerja yang dihasilkan oleh karyawan akan semakin rendah jika stres kerja yang dialami karyawan semakin tinggi. Sehingga untuk tetap mempertahankan karyawan agar dapat tetap bekerja, perusahaan harus mampu menyesuaikan pekerjaan yang diberikan dengan kemampuan dan keahlian yang dimiliki setiap karyawan. dengan membuat jam kerja yang jelas, memperbaiki pendapatan atau gaji yang diterima karyawan serta memberikan perhatian terhadap masalah yang sedang dihadapi oleh karyawan baik masalah yang berkaitan dengan pekerjaan maupun masalah kehidupan pribadinya.

Atkinson dkk (1990), mengungkapkan stres dikatakan positif jika stres tersebut merupakan suatu peluang dan dapat merangsang karyawan untuk meningkatkan usahanya dalam memperoleh hasil kerja yang maksimal dan stres mengakibatkan timbulnya konsekuensi penurunan atau peningkatan usaha baik jangka pendek maupun jangka panjang. Sehingga dalam mengendalikan stres kerja, perusahaan wajib mengawalinya dengan mencari penyebab stres kerja.

Karyawan merasa tidak ada tantangan kerja jika tidak adanya stres kerja sehingga kinerja yang dihasilkan oleh karyawan menurun. Sebaliknya juga akan demikian, karena dengan adanya stres maka karyawan mendapatkan dorongan untuk mengerahkan kemampuan dan keterampilan yang dimiliki untuk menyelesaikan pekerjaan yang telah diberikan oleh perusahaan sebaik mungkin. Stres kerja akan mencapai titik stabil sesuai dengan kemampuan dan keterampilan seorang karyawan jika stres yang dirasakan meningkat. Kinerja yang dihasilkan karyawan akan cenderung menurun karena karyawan merasa stres yang dirasakan mulai mengganggu dalam menyelesaikan pekerjaan mereka. Kinerja karyawan menjadi sangat turun bahkan nol, merasa putus asa, tidak sanggup lagi untuk bekerja dan memilih keluar dari pekerjaan mereka untuk menghindari stres yang semakin bertambah merupakan dampak yang paling menakutkan jika karyawan tidak dapat mengendalikan stres kerja yang mereka alami dengan baik. Karyawan akan kehilangan kemampuan

Robbins (1996), berpendapat bahwa, hubungan stres kerja dengan kinerja disajikan dalam model U-terbalik. Hubungan U-terbalik didasari logika bahwa tubuh akan merangsang seseorang untuk meningkatkan kemampuan dalam berkreasi dan menyelesaikan tugas dengan baik jika stres yang dialami pada tingkat stres kerja rendah sampai stres kerja sedang. Pada situasi ini pekerjaan yang dilakukan oleh seseorang akan diselesaikan dengan baik dan cenderung cepat selesa. Sebaliknya, kinerja akan cenderung menurun jika stres yang dialami pada tingkat lanjut sehingga mengakibatkan perubahan perilaku, mental dan kinerja kearah yang negatif.

Menurut Hasibuan (2012) stres dapat memicu terjadinya penurunan kinerja karyawan. Karyawan yang merasa stres cenderung mengalami ketegangan pikiran dan berperilaku aneh, mudah marah, dan suka menyendiri sehingga prestasi kerja dari karyawan tidak akan tercapai secara optimal.

Rusdi dkk (2008), menjelaskan bahwa para ahli menyatakan stres kerja sebagai sebab dari berbagai masalah baik secara fisik maupun mental. Stres kerja yang berdampak negatif tidak hanya mempunyai pengaruh terhadap diri sendiri namun juga berpengaruh terhadap organisasi, akibatnya kepuasan kerja, kinerja dan ketidakhadiran dari sekumpulan individu tersebut akan terganggu. Stres yang berdampak negatif maupun positif mempengaruhi kinerja dari karyawan. Stres yang berdampak positif dapat meningkatkan kinerja dari karyawan, sebaliknya jika stres berdampak negatif maka akan membuat kinerja akan menurun.

\section{SIMPULAN}

Hasil distribusi kompensasi diketahui bahwa sebagian besar karyawan mendapatkan kompensasi 
tinggi yaitu $40 \%$. Sebagian besar karyawan yang mendapat kompensasi tinggi adalah karyawan yang telah lama bekerja di PT. Dok dan Perkapalan Surabaya (Persero).

Karyawan bagian konstruksi sebagian besar mengalami stres sedang yaitu $77,5 \%$. Dan untuk distribusi kinerja diketahui bahwa sebagian besar karyawan memiliki kinerja baik yaitu $65 \%$. Hal ini disebabkan karena karyawan merasa diberikan tanggung jawab atau pekerjaan sesuai dengan keterampilan yang mereka miliki.

Hasil perhitungan menggunakan korelasi Spearrman antara variabel kompensasi finansial dan kinerja didapatkan nilai korelasi koefisien sebesar 0,332 , maka dapat diinterpretasikan bahwa tingkat hubungan kedua variabel adalah sedang. Perhitungan antara variabel stres kerja dan kinerja karyawan didapatkan hasil korelasi koefisien sebesar 0,445, yang dapat diartikan bahwa tingkat hubungan kedia variabel adalah sedang.

\section{DAFTAR PUSTAKA}

As'ad, M. 2004. Psikologi Industri, Seri Umum. Sumber Daya Manusia. Edisi 4. Yogyakarta: Liberty.

Atkinson, Rila L. Richard C. Atkinson. Edward, ES., Daryl JB. Pengantar Psikologi, Edisi Kesebelas, Jilid Satu, Alih Bahasa Wijaya Kusuma. Interaksara.

Dhermawan, A.A.N.B., Sudibya, I.G.A., Utama, I.W.M. 2012. Pengaruh Motivasi, Lingkungan Kerja, Kompetensi, dan Kompensasi terhadap Kepuasan Kerja dan Kinerja Pegawai di Lingkungan Kantor Dinas Pekerjaan Umum Provinsi Bali. Jurnal Manajemen, strategi Bisnis dan Kewirausahaan, 6(2): 173-184.

Effendy, O.U. 2007. Ilmu Komunikasi (Teori dan Praktek). Bandung: PT. Remaja Rosdakarya.

Handoko, T.H. 2000. Manajemen Personalia dan Sumberdaya Manusia, Edisi II, Cetakan Keempat Belas. Yogyakarta: BPFE.

Handoko, T.H. 2001. Manajemen Personalia dan Sumber Daya Manusia, Edisi kedua. Yogyakarta: BPFE.

Hasibuan, M. 2003. "Organisasi dan Motivasi". Jakarta: Bumi Aksara.

Hasibuan, M. 2012. Manajemen Sumber Daya Manusia. Edisi Revisi. Jakarta: PT. Bumi Aksara.
Hidayati, R., Purwanto, Yadi. dan Yuwono, Susatyo . 2008. Kecerdasan Emosi, Stres Kerja dan Kinerja Karyawan. Jurnal Psikologi, 2(1): 91-96.

Mangkunegara, A.P. 2009. Manajemen Sumber Daya Manusia. Bandung: PT. Remaja Rosdakarya.

Mathis., Jackson. 2002. Manajemen Sumber Daya Manusia, Edisi pertama, Cetakan Pertama, Yogyakarta: Salemba Empat

Muljani, N. 2002. Kompensasi Sebagai Motivator Untuk Meningkatkan Kinerja Karyawan. Jurnal Manajemen dan Kewirausahaan,4 (2), 108-122.

Notoatmodjo, S. 2005. Metode Penelitian Kesehatan. Jakarta: Rineka Cipta.

Panggabean., Mutiara, S. 2002. Manajemen Sumber Daya Manusia, Bogor: Ghalia Indonesia.

Putri. D.Y. 2012. Pengaruh Stres Kerja dan Komitmen Organisasional terhadap Kinerja Sales Person Dengan Pengalaman Kerja sebagai Variabel Modetoring pada PT. United Motors Centre Pusat Surabaya. Skripsi. Surabaya: Universitas Airlangga.

Robbins, S.P. 1996. Perilaku Organisasi Jilid 2 Alih Bahasa Hadyana Pujaatmaka. Jakarta: PT. Prenhallindo.

Robbins, S.P., Timothy A.J. 2008. Perilaku Organisasi. Edisi ke-12,Jakarta: Salemba Empat.

Rusdi, R., Dian Septiani. 2008. Pengaruh Stres Kerja terhadap Kinerja Karyawan pada Bagian Redaksi Surat Kabar Harian Umum Lampung Post. Jurnal Bisnis dan Manajemen, 4(2): 201-219.

Sedarmayanti. 2009. Sumber Daya Manusia dan Produktivitas Kerja. Edisi ketiga. Bandung: Mandar Maju.

Simamora, H. 2004. Manajemen Sumber Daya Manusia. Edisi ketiga. Yogyakarta: Aditya Media.

Subkhi. 2012. Managerial Development, Jakarta: Andi.

Sulistiyowati, F. 2005. Pengaruh Penghasilan Terhadap Efektivitas Kinerja Kepala Perangkat Daerah Studi Kasus pada Pemerintah Kota Yogyakarta Tahun2003. Jurnal Akuntansi dan Keuangan Sektor Publik 06 (01), 27-54.

Tarwaka. 2011. Ergonomi Industri Dasar-dasar Pengetahuan Ergonomi dan Aplikasi di Tempat Kerja. Surakarta: Harapan Offset.

Wijono, S. 2012 Psikologi Industri dan Organisasi. Jakarta: Kencana Prenada Media Group.

Winarsunu. T. 2008. Psikologi Keselamatan Kerja. Malang: UMM Press. 
Yani, M. 2016. Hubungan Kompensasi dan Stres Kerja dengan Kinerja Karyawan PT. Dok dan Perkapalan Surabaya (Persero), Skripsi: Fakultas Kesehatan Masyarakat Universitas Airlangga. Yensy., N.A. 2010. Pengaruh Kompensasi dan Motifasi Terhadap Kinerja Guru di SMA Negeri 2 Argamakmur Bengkulu Utara. Jurnal Kependidikan Triadik, 4(1): 33-42.
Yulianto, R.B. Pengaruh Kompensasi Finansial dan Non Finansial terhadap Kinerja Karyawan Bagian Tanaman Pabrik Gula Djatiroto dengan Komitmen Organisasional sebagai Variabel Intervening. Skripsi. Surabaya: Universitas Airlangga. 